\title{
Violence in Films and Society
}

\author{
M. Nazir Mahmood \\ Development Consultant, \\ $M \& E$ and Education Management \\ Islamabad \\ mnazir1964@yahoo.co.uk
}

Violence in films is not a new phenomenon. For over a hundred years, films have depicted social issues that deal with violence. The violence depicted in The Birth of a Nation almost a century ago was of a racist nature. The Ku Klux Klan targeted black people after the American Civil War and the film was sympathetic towards this violence. It tried to justify what white supremacists were doing to former slaves. If you watch that movie now, you wonder how that utterly racist movie was allowed to be shown in cinema houses across America.

Despite the violence that The Birth of a Nation showed and eulogized, the film did became a cult classic and drew critical appreciation. Its success was due less to its racist message and more thanks to its technical details, as introduced by its director D.W. Griffith. With the release of The Birth of a Nation in 1915, violence became an acceptable part of almost any movie. Then the gangster movies of the 1920s and 30s, mostly casting James Cagney and Paul Muni in movies such as The Public Enemy (1931) and Scarface brought, street violence to the screen as oppose to the mass violence of epic films.

Four movies that stand out as amongst the early examples of an anti-war narratives that expose violence as a useless method of achieving superiority are All Quiet on the Western Front (1930), A Farewell to Arms (1932), which was based on a novel by the American writer Ernest Hemingway, Grand Illusion (1937) directed by Jean Renoir, and a tragicomedy by Charlie Chaplin, The Great Dictator (1940). In the 1940s and '50s, film noir, with mostly low budgets and B-movies took over 
Hollywood. They used innovative shooting and lighting techniques to evoke a mood of anxiety in the post-war period.

In this genre or movement, five films deserve especial mention: John Huston's The Maltese Falcon (1941), Edward Dmytryk's Murder, My Sweet (1944), Billy Wilder's Double Indemnity (1944), Otto Preminger's Laura (all 1944), and Wilder's The Lost Weekend (1945), all rooted in American fiction. These five films depict the violence used by cynical detectives and ruthless crooks on corrupt officials and drifters. In these films, violence emerged with a new political and psychoanalytical dimension.Violence was meted out not only by established stars such as Humphrey Bogart, Barbara Stanwyck, and Edward G. Robinson but also by newcomers of that period, e.g. Robert Mitchum, Gloria Grahame, and Richard Widmark.

Violence in war movies was a favourite topic for film directors, immediately after the Second World War, but initially the war violence was depicted as being a necessary evil and part of of a just warfare. For example, films such as The Bridge on the River Kwai, Where Eagles Dare, Von Ryan's Express, Heroes of Telemark, The Guns of Navarrone, The Great Escape (1963) and many others showed heroes of the Allied forces who used violence only when it was absolutely necessary. In this way violence is justified and war heroes are lionized. But this trend changed after the Vietnam War ended, in 1975, in a humiliating defeat for the USA.

Through noir went out of vogue, its influence continued around the world, e.g. in Japan Akira Kurosawa showed violence in intimate detail—be it The Seven Samurai (1954), Throne of Blood, or RAN in the 1980s. In the 1970s, violence in American cinema was reflected in movies either with a Vietnam background, such as The Deer Hunter, Apocalypse Now (1979), and Platoon; or at individual level, such as in Chinatown (1974).

In the early 1980s, three films made depicting political violence in revolutions and civil wars were Reds (1981), about the Soviet revolution of 1917; First Blood (1982), showing the aftermath of violence in the Vietnam War, and the Killing Fields (1984), showing the horrific results of the civil war in Cambodia and Khmer Rouge fighters as perpetrators of ruthless violence under the command of Pol Pot. In Pakistan, the 1970s and '80s were a period resembling the Dark Ages in Pakistan with General Ziaul Haq in power, seeking to destroy democracy and politics in Pakistan. 
It was also the period when films such as Maula Jut and Son of Maula Jut were being made. Violence in Pakistani films was adorning the screens with names such as Jagga, Gujjar, Badmash, Juts, Wehshis, Qatils, and many more. Those who wonder why Pakistani society has become so violent should watch some of the Punjabi movies made during the past forty years since General Ziaul Haq took over and started lashing and whipping not only political workers but also journalists. All this violence has now penetrated the fabric of Pakistani society and there appears to be no way out.

After the so called war on terror was launched in the wake of the 9/11 attacks on the US, violence in movies has become a regular feature, especially in those movies that show the state apparatus cracking down on terrorists. A new phenomenon is Pakistan is the movies made by the ISPR that show violence being perpetrated by the terrorists and counter violence being meted out to them by the soldiers. While these films depict terrorist violence as bad and state violence as good, they fail to give an honest account of why we have ended up in the sorry state where violence has become an everyday affairs and almost nobody is safe from sudden violence anywhere. 